\title{
Pengaruh Teknologi Informasi dan Pengendalian Internal Terhadap Kualitas Sistem Informasi Akuntansi Manajemen pada AUTO2000 Kenjeran Surabaya
}

\author{
Fuad adi Nugroho, Hendy Widiastoeti, Arga Christian Sitohang \\ Fakultas Ekonomi Universitas 17 Agustus 1945 Surabaya \\ Email corresponding author: hendi@untag-sby.ac.id, argasitohang@untag-sby.ac.id
}

\begin{abstract}
ABSTRAK
Penelitian ini bertujuan untuk menganalisis pengaruh teknologi informasi dan pengendalian internal terhadap kualitas sistem informasi akuntansi manajemen pada AUTO2000 Kenjeran Surabaya. Penelitian ini menggunakan data primer yang diperoleh melalui penyebaran kuesioner kepada 30 responden, kemudian pertanyaan-pertanyaan dalam kuesioner dibagi menjadi tiga kategori Dimana terdapat 6 pertanyaan mengenai teknologi informasi, 4 pertanyaan mengenai pengendalian intern, dan 9 pertanyaan mengenai sistem akuntansi manajemen. Dalam penelitian ini digunakan karyawan AUTO2000 Kenjeran di Kecamatan Mulyorejo Surabaya sebagai objek penelitian. Metode analisis yang digunakan adalah kuantitatif data yang diukur dengan satuan skor. Metode analisis yang digunakan adalah regresi linier berganda setelah diuji dengan model asumsi klasik. Hasil analisis menunjukkan bahwa teknologi informasi dan pengendalian intern berpengaruh terhadap kualitas sistem informasi akuntansi manajemen. Manajemen sebaiknya menerapkan pengendalian intern secara tepat mengingat bahwa tugas perusahaan semakin kompleks sehingga dapat membantu meningkatkan kinerja perusahaan
\end{abstract}

Kata Kunci: Teknologi Informasi, Pengendalian Internal dan Kualitas sistem informasi akuntansi manajemen

\section{PENDAHULUAN}

Perkembangan teknologi yang sangat cepat saat ini telah banyak memberikan manfaat pada bidang ekonomi. Teknologi juga telah mendorong manusia untuk dengan mudah menyelesaikan pekerjaan yang dimiliki. Peranan teknologi informasi dalam berbagai aspek kegiatan bisnis dapat dipahami karena sebagai sebuah teknologi yang menitikberatkan pada pengaturan sistem informasi dengan penggunaan komputer, teknologi informasi dapat memenuhi kebutuhan informasi dunia bisnis dengan sangat cepat, tepat waktu, relevan, dan akurat. Menurut Wilkinson dan Cerullo (1997) hampir semua perusahaan bisnis menggunakan mikrokomputer dan komputer induk sebagai bagian yang saling terintegrasi dalam sistem informasi. Kebutuhan akan komputer untuk menunjang terciptanya informasi yang akurat sangatlah besar.

Sistem Informasi Akuntansi merupakan kumpulan dari subsistem subsistem yang saling berhubungan satu sama lain dan bekerja sama secara harmonis untuk mengolah data keuangan menjadi informasi keuangan yang diperlukan oleh pengambil keputusan dalam proses 
pengambilan keputusan Azhar Susanto (2009:18). Keberhasilan penerapan sistem informasi dapat terwujud tergantung pada penggunaan sistem itu dijalankan, mudahnya sistem digunakan, dan teknologi yang dipakai (Jumaili, 2005:723). Fungsi dari Sistem Informasi Akuntansi yaitu untuk mengumpulkan dan menyimpan aktivitas yang dilaksanakan di suatu perusahaan, mengubah data menjadi informasi yang berguna bagi pihak manajemen, dan menyediakan pengendalian yang memadai sebagai pendukung pengambilan keputusan, pendukung kegiatan operasional, perencanaan, pengendalian, dan perbaikan dimasa yang akan datang Fairus La Rosa Nanda dan Mardi (2011:5).

Kualitas sistem informasi akuntansi adalah integrasi semua unsur dan subunsur yang terkait dalam membentuk sistem informasi akuntansi untuk 4 menghasilkan informasi yang berkualitas. Unsur-unsur yang terintegrasi tersebut disebut juga sebagai komponen sistem informasi akuntansi yang terdiri dari Hardware, Software, Brainware, Prosedur, Database dan Jaringan komunikasi (Azhar Susanto, 2013: 14).

Dalam dunia modern, kualitas informasi yang kuat dalam hal itu mengarahkan masa depan bisnis. Hal ini karena kualitas informasi yang baik dapat membawa kesuksesan, sementara kualitas informasi yang buruk dapat menyebabkan kegagalan usaha (Bovee 2004, Redman 1998; Redman 2008). Akibatnya kriteria kualitas informasi telah menjadi pertimbangan penting bagi setiap organisasi yang ingin melakukan berbagai proses dengan baik. Secara khusus, akuntansi dan manajemen membuat perhatian dengan ketepatan SIA, agar kebutuhan organisasi untuk informasi komunikasi dan control (Gordon dan Militer 1976; Mc Laneydan Atrill 2005). Untuk menjawab pertanyaan penelitian ini, peneliti merumuskan pertanyaan penelitian sebagai berikut:

1. Apakah teknologi informasi memiliki pengaruh yang signifikan terhadap kualitas sistem informasi akuntansi manajemen pada AUTO2000 Kenjeran di Kecamatan Mulyorejo Surabaya?

2. Apakah pengendalian internal memiliki pengaruh yang signifikan terhadap kualitas sistem informasi akuntansi manajemen pada AUTO2000 Kenjeran di Kecamatan Mulyorejo Surabaya?

3. Apakah teknologi informasi dan pengendalian internal secara bersama-sama berpengaruh signifikan terhadap kualitas sistem informasi akuntansi manajemen pada AUTO2000 Kenjeran di Kecamatan Mulyorejo Surabaya?

\section{KAJIAN PUSTAKA}

\section{Pengertian Akuntansi Manajemen}

Menurut Blocher \& Cokins (2011) mendefinisikan bahwa akuntansi manajemen adalah suatu profesi yang melibatkan kemitraan dalam pengambilan keputusan manajemen, menyusun perencanaan dan sistem manajemen kinerja, serta menyediakan keahlian dalam pelaporan keuangan dan pengendalian untuk membantu manajemen dalam memformulasikan dan mengimplementasikan suatu strategi organisasi.

Sedangkan menurut Simamora (2012) akuntansi Manajemen adalah Proses pengidentifikasian, pengukuran penghimpunan, penganalisaan, penyusunan, penafsiran dan pengkomunikasian informasi keuangan yang digunakan oleh manajemen untuk merencanakan, mengevaluasi dan mengendalikan kegiatan usaha di dalam sebuah organisasi, serta untuk memastikan penggunaan dan akuntabilitas sumber daya yang tepat.

Menurut Siregar, Suripto, dkk (2013) mendefinisikan bahwa akuntansi Manajemen adalah proses mengidentifikasi, mengukur, mengakumulasi, menyiapkan, menganalisis, menginterpretasikan, dan mengomunikasikan kejadian ekonomi yang digunakan oleh 
manajemen untuk melakukan perencanaan, pengendalian, pengambilan keputusan dan penilaian kinerja dalam organisasi.

\section{Pengertian Sistem Informasi Akuntansi Manajemen}

Menurut Baldric Siregar, dkk (2013:5) sistem informasi akuntansi manajemen yaitu: "Sistem informasi yang mentransformasi input dengan menggunakan proses untuk mengeluarkan output yang dibutuhkan untuk mendukung pengambilan keputusan".

Sedangkan menurut Hansen dan Mowen (2010:4) sistem informasi akuntansi manajemen adalah:

"Sistem informasi yang menghasilkan keluaran (output) dengan menggunakan masukan (input) dan berbagai proses yang diperlukan untuk memenuhi tujuan tertentu manajemen." Berdasarkan pengertian sistem informasi akuntansi manajemen di atas, dapat disimpulkan bahwa sistem informasi akuntansi manajemen adalah suatu sistem yang dirancang untuk mengolah input yang berupa data keuangan dan non keuangan menjadi output dalam bentuk informasi bagi para manajer dalam menjalankan aktivitas manajerial

\section{Pengertian Teknologi Informasi}

Teknologi informasi pada saat ini sangat berperan dalam mendukung kegiatan organisasi atau perusahaan agar kegiatan suatu perusahaan bisa berjalan lebih efektif dan efisien. Selain sebagai teknologi komputer (hardware dan software) untuk pemrosesan dan penyimpanan informasi, juga berfungsi sebagai teknologi komunikasi untuk penyebaran informasi. Komputer sebagai salah satu komponen dari teknologi informasi merupakan alat yang bisa melipatgandakan 18 kemampuan yang dimiliki manusia dan komputer juga bisa mengerjakan sesuatu yang manusia mungkin tidak mampu melakukannya.

Menurut Williams dan Sawyer (2011:4), definisi teknologi informasi adalah sebagai berikut:"Information technology (IT) is a general term that describes any technology that helps to produce, manipulate, store, communicate and or disseminate information"

Sedangkan Tata Sutabri (2014:3) definisi teknologi informasi adalah sebagai berikut:"Suatu teknologi yang digunakan untuk mengolah data, termasuk memproses, mendapatkan, menyusun, menyimpan, memanipulasi data dalam berbagi cara untuk menghasilkan informasi yang berkualitas, yaitu informasi yang relevan, akurat dan tepat waktu, yang digunakan untuk keperluan pribadi, bisnis dan pemerintahan dan merupakan informasi yang strategis untuk mengambil keputusan."

Menurut Sutarman (2012:13), definisi teknologi informasi adalah sebagai berikut:Suatu studi, perancangan, pengembangan, implementasi, dukungan atau manajemen sistem informasi berbasis komputer, khususnya aplikasi perangkat lunak dan perangkat keras komputer."

\section{Pengendalian Internal}

Dalam teori akuntansi dan organisasi, pengendalian intern atau kontrol intern didefinisikan sebagai suatu proses, yang dipengaruhi oleh sumber daya manusia dan sistem teknologi informasi, yang dirancang untuk membantu organisasi mencapai suatu tujuan atau objektif tertentu. Pengendalian intern merupakan suatu cara untuk mengarahkan, mengawasi, dan mengukur sumber daya suatu organisasi. Ia berperan penting untuk mencegah dan mendeteksi penggelapan (fraud) dan melindungi sumber daya organisasi baik yang berwujud (seperti mesin dan lahan) maupun tidak berwujud (seperti reputasi atau hak kekayaan intelektual seperti merek dagang).

Adanya sistem akuntansi yang memadai, menjadikan akuntan perusahaan dapat menyediakan informasi keuangan bagi setiap tingkatan manajemen, para pemilik atau pemegang saham, kreditur dan para pemakai laporan keuangan (stakeholder) lain yang 
dijadikan dasar pengambilan keputusan ekonomi. Sistem tersebut dapat digunakan oleh manajemen untuk merencanakan dan mengendalikan operasi perusahaan. Lebih rinci lagi, kebijakan dan prosedur yang digunakan secara langsung dimaksudkan untuk mencapai sasaran dan menjamin atau menyediakan laporan keuangan yang tepat serta menjamin ditaatinya atau dipatuhinya hukum dan peraturan, hal ini disebut Pengendalian Intern, atau dengan kata lain bahwa pengendalian intern terdiri atas kebijakan dan prosedur yang digunakan dalam operasi perusahaan untuk menyediakan informasi keuangan yang handal serta menjamin dipatuhinya hukum dan peraturan yang berlaku.

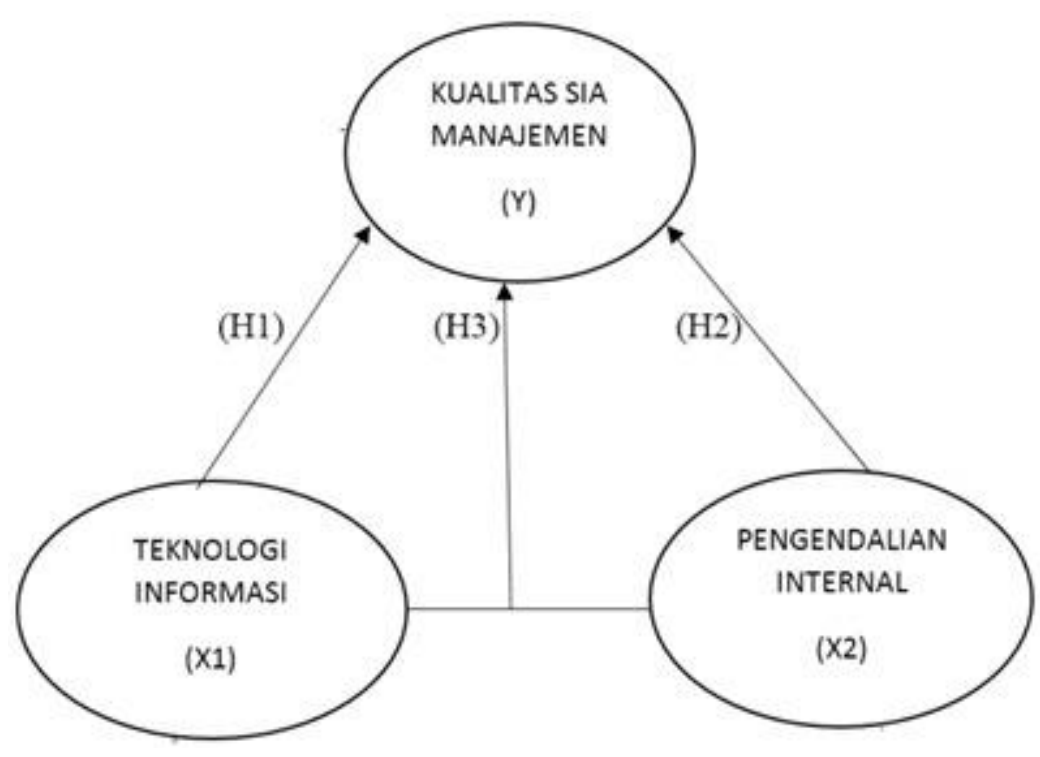

METODE PENILITIAN

Desain penelitian yang digunakan dalam penelitian ini adalah desain ex post facto. Tujuannya adalah untuk mengetahui apakah ada hubungan teknologi informasi dan pengendalian intern dengan kualitas sistem informasi akuntansi manajemen. Peneliti menyebarkan kuesioner terhadap sampel karyawan perusahaan. Isi kuesioner tersebut menyangkut pertanyaanpertanyaan untuk mengukur tingkat teknologi informasi dan pengendalian intern dengan kualitas SIAM. Peneliti hanya mencatat dan melaporkan data apa adanya, kemudian menganalisis hubungan variabel tersebut dengan menggunakan analisis korelasional, untuk menentukan ada tidaknya hubungan variabel tersebut.

\section{Waktu Penelitian}

Waktu yang digunakan peneliti untuk penelitian ini dilaksanakan sejak tanggal dikeluarkannya ijin penelitian dalam kurun waktu kurang lebih 2 (dua) bulan, 1 bulan pengumpulan data dan 1 bulan pengolahan data yang meliputi penyajian dalam bentuk skripsi dan proses bimbingan berlangsung.

\section{Tempat Penelitian}

Tempat pelaksanaan penelitian ini adalah di perusahaan Auto2000 Kenjeran, Jalan Raya Kenjeran No. 522-524 Surabaya. 


\section{Populasi}

Populasi dalam penelitian ini adalah manajer, pimpinan unit, dan karyawan yang ada pada AUTO2000 Kenjeran di Kecamatan Mulyorejo Surabaya yang menjadi objek penelitian.

\section{Sampel}

Untuk menentukan sample menggunakan teknik sample jenuh yaitu teknik penentuan sample yang menjadikan semua populasi sebagai sampel. Sampel dalam penelitian ini adalah manajer, pimpinan, dan karyawan pada AUTO2000 Kenjeran di Kecamatan Mulyorejo Surabaya.

\section{Pengumpulan Data}

Proses pengolahan data dengan menggunakan staktistik deskriptif merupakan statistic yang di gunakan untuk menganalisa data dengan cara mendeskripsikan atau menggabarkan data yang telah terkumpul, sebagaimana adanya tanpa bermaksud membuat kesimpulan yang berlaku untuk umum atau regenelasi.

\section{Analisis Data}

Metode analisis data adalah suatu metode yang digunakan untuk mengolah hasil penelitian guna memperoleh suatu kesimpulan. Penelitian ini metode analisis data yang digunakan adalah sebagai berikut: Deskriptif Digunakan untuk mengetahui dan menganalisis data mengenai variabel teknologi informasi, pengendalian internal dan kualitas sistem informasi akuntansi manajemen.

\section{HASIL PENELITIAN}

\section{Uji Regresi Berganda}

Pengujian hipotesis menggunakan analisis regresi linier berganda. Dalam analisis regresi selain mengukur kekuatan hubungan antara dua variabel atau lebih, juga menunjukkan arah hubungan antar variabel dependen dengan variabel independen. Variabel dependen diasumsikanrandom berarti mempunyai distribusi probabilistik. Variabel independen diasumsikan memiliki nilai tetap. Berdasarkan analisis regresi ini kemudian dilanjutkan dengan metode analisis jalur (path analysis). Analisis jalur merupakan perluasan dari analisis regresi linier berganda. Analisis jalur adalah penggunaan analisis regresi untuk menaksir hubungan kausalitas antar variabel yang telah ditetapkan sebelumnya berdasarkan teori. Hubungan langsung terjadi jika teknologi informasi mempengaruhi kinerja tanpa ada sistem akuntansi manajemen (SAM). Persamaan model regresi

$$
Y=a+\beta_{1} \cdot x_{1}+\beta_{2} \cdot x_{2}+\mathrm{e}
$$

$\mathrm{Y}=$ Kinerja manajer

$\mathrm{a}=$ konstanta regresi

$\beta_{1} \cdot \beta_{2}=$ koefisien regresi

$x_{1}=$ variabel karakteristik informasi system akuntansi manajemen

(informasi broad scope, informasi time lines, informasi agregatiosn, Informasi intergrations) $\mathrm{X} 1, \mathrm{X} 2$ = interaksi antara variabel $\mathrm{X} 1$ dan $\mathrm{X} 2$

\section{Pengujian Hipotesis}

Uji t pada dasarnya menunjukan seberapa jauh pengaruh satu variable independen secara individual dalam menerangkan variable dependen (Ghozali, 2013:86). Pengujian dilakukan dengan menggunakan signifikan level 0,05 $(\mathrm{a}=5 \%)$. 
Penerimaan atau penolakan hipotesis dilakukan dengan kriteria:

a. Jika nilai signifikan >0,05 maka hipotesis ditolak (koefisien regresi tidak signifikan). Ini berarti secara parsial variable independen tidak mempunyai pengaruh secara signifikan terhadap variable dependen.

b. Jika nilai signifikan $<0,05$ maka hipotesis diterima (koefisien regresi signifikan). Ini berarti secara parsial variable independen tersebut mempunyai pengaruh yang signifikan terhadap varibale dependen.

Tabel 1. Uji T dan Linier Berganda

Coefficients $^{\mathrm{a}}$

\begin{tabular}{|c|c|c|c|c|c|}
\hline \multirow[b]{2}{*}{ Model } & \multicolumn{2}{|c|}{$\begin{array}{c}\text { Unstandardized } \\
\text { Coefficients }\end{array}$} & \multirow{2}{*}{$\begin{array}{c}\begin{array}{c}\text { Standardized } \\
\text { Coefficients }\end{array} \\
\text { Beta } \\
\end{array}$} & \multirow[b]{2}{*}{$\mathrm{T}$} & \multirow[b]{2}{*}{ Sig. } \\
\hline & B & Std. Error & & & \\
\hline 1 (Constant) & 11.184 & 5.419 & & 2.064 & .049 \\
\hline DISENTRALISASI & .354 & .128 & .428 & 2.771 & .010 \\
\hline SAM & .312 & .125 & .386 & 2.500 & .019 \\
\hline
\end{tabular}

Sumber: Data primier setelah diolah, 2020 menggunakan SPSS

\section{Pengaruh Variabel Teknologi Informasi Signifikan Terhadap Kualitas Sistem Informasi Akuntansi Manajemen $\left(H_{1}\right)$}

Variabel Teknologi Informasi (X1) berpengaruh secara positif dan signifikan terhadap kualitas sistem informasi akuntansi manajemen. Hal ini terlihat dari signifikan teknologi informasi (X1) $0,01<0,05$, dan nilai t tabel 2,46714. Berarti nilai t hitung lebih besar dari t tabel $(2,771$ $>2,46714$ ), maka $H_{0}$ ditolak dan $H_{1}$ diterima. Sehingga hipotesis yang berbunyi terdapat pengaruh teknologi informasi terhadap kualitas sistem informasi akuntansi manajemen secara parsial diterima.

\section{Pengaruh Variabel Pengendalian Internal Signifikan Terhadap Kualitas Sistem Informasi Akuntansi Manajemen $\left(\mathrm{H}_{2}\right)$}

Variabel pengendalian internal (X2) berpengaruh secara positif dan signifikan terhadap kualitas sistem informasi akuntansi manajemen. Hal ini terlihat dari signifikan pengendalian internal (X2) $0,019<0,05$, dan nilai t tabel 2,46714. Berarti nilai t hitung lebih besar dari t tabel $(2,500$ $>2,46714$ ), maka $H_{0}$ ditolak dan $\mathrm{H}_{2}$ diterima. Sehingga hipotesis yang berbunyi terdapat pengaruh pengendalian internal terhadap kualitas sistem informasi akuntansi manajemen secara parsial diterima.

\section{Uji F (Simultan)}

Uji statistik F pada dasarnya menunjukan apakah semua variable independen yang dimasukkan dalam model mempunyai pengaruh secara bersama-sama terahdap variable terikat. Adapun prosedur pengujian yang digunakan sebagai berikut:

a. Jika nilai $\mathrm{F}$ hitung $>\mathrm{F}$ tabel maka variable bebas secara bersama-sama bepengaruh terhadap variable terikat.

b. Jika nilai $\mathrm{F}$ hitung < $\mathrm{F}$ tabel maka variable bebas secara bersama-sama tidak berpengaruh terhadap variable terikat. 
Tabel 2. Uji F (Bersama-Sama)

ANOVA $^{\mathrm{a}}$

\begin{tabular}{|ll|r|r|r|r|r|}
\hline & & Sum of & & Mean & & \\
Model & & Squares & Df & Square & F & Sig. \\
\hline 1 & Regression & 72.384 & 2 & 36.192 & 7.639 &, $002^{\mathrm{b}}$ \\
& & & & & \\
& Residual & 127.916 & 27 & 4.738 & & \\
& Total & 200.300 & 29 & & & \\
\hline
\end{tabular}

Dependent Variable: KINERJA

Predictors: (Constant), SAM, DISENTRALISASI

Sumber: Data primier setelah diolah, 2020

Berdasarkan hasil pengujian pada tabel di atas dilihat pada nilai $\mathrm{F}$ hitung sebesar 7,693 dengan nilai $\mathrm{F}$ tabel adalah 3,09 sehingga nilai $\mathrm{F}$ hitung $>\mathrm{F}$ tabel atau 7,693 > 3,09, dan tingkat signifikan 0,002 < 0,05 maka $H_{0}$ ditolak dan $H_{3}$ diterima, dapat disimpulkan bahwa Teknologi Informasi (X1), Pengendalian Internal (X2) dan secara bersama-sama berpengaruh signifikan terhadap Kualitas Sistem Informasi Akuntansi Manajemen.

\section{Uji Koefisien Determinasi}

Koefisien determinasi $\left(\boldsymbol{R}^{2}\right)$ pada intinya mengukur seberapa jauh kemampuan model dalam menerangkan variasi variable independen. Nilai koefisien determinasi adalah antara nol dan satu. Nilai $R^{2}$ yang kecil berarti kemampuan variasi variable dependen sangat terbatas. Nilai yang mendekati satu berarti variable-variable independen memberikan hampir semua informasi yang dibutuhkan untuk memprediksi variasi variable dependen.

Tabel 3. Uji Koefisiensi Determinasi $\left(\mathrm{R}^{2}\right)$

Model Summary ${ }^{\mathrm{b}}$

\begin{tabular}{|c|c|c|c|c|c|}
\hline Model & $\mathrm{R}$ & R Square & $\begin{array}{c}\text { Adjusted R } \\
\text { Square } \\
\end{array}$ & $\begin{array}{l}\text { Std. Error of } \\
\text { the Estimate }\end{array}$ & Durbin-Watson \\
\hline 1 &, $601^{\mathrm{a}}$ & .591 & .587 & 2.177 & 2.302 \\
\hline
\end{tabular}

Sumber: Data primier setelah diolah, 2020 SPSS

Berdasarkan hasil pengujian pada tabel diatas nilai adjusted $R^{2}$ sebesar 0,587. Hal ini berarti kemampuan variabel bebas dalam menjelaskan variabel terikat adalah sebesar 58,7\%, sisanya 42,3\% dijelaskan oleh variabel lain yang tidak dibahas dalam penelitian ini. sebelumnya.

Berikut ini akan dijelaskan hasil pengujian atas hipotesis yang telah dirumuskan

\section{Hipotesis 1: Pengaruhi Signifikan dan Positif Teknologi Informasi Terhadap Kualitas Sistem Informasi Akuntansi Manajemen}

Hipotesis yang pertama dalam penelitian ini ialah Teknologi Informasi berpengaruh signifikan terhadap Kualitas Sistem Informasi Akuntansi Manajemen. Hasil dari pengujian uji t menunjukkan bahwa nilai signifikan untuk variabel Teknologi Informasi sebesar 0,001. Nilai ini lebih kecil dari tingkat signifikansi sebesar 0,05, sehingga dapat disimpulkan bahwa Teknologi Informasi secara individual berpengaruh secara signifikan dan positif terhadap 
Kualitas Sistem Informasi Akuntansi Manajemen. Berdasarkan hasil pengujian di atas dapat disimpulkan bahwa hipotesis pertama diterima.

Hasil ini sesuai dengan hasil penelitian Fadila Ariesta (2013) menyebutkan bahwa terdapat pengaruh yang signifikan dan positif Teknologi Informasi terhadap Kualitas Sistem Informasi Akuntansi Manajemen.

\section{Hipotesis 2: Pengendalian Internal Berpengaruh Signifikan Terhadap Kualitas Sistem Informasi Akuntansi Manajemen}

Hipotesis kedua dalam penelitian ini ialah Pengendalian Internal berpengaruh signifikan terhadap Kualitas Sistem Informasi Akuntansi Manajemen. Hasil dari pengujian uji t menunjukkan bahwa nilai signifikan untuk Pengendalian Internal sebesar 0,019. Nilai ini lebih kecil dari tingkat signifikansi sebesar 0,05, sehingga dapat disimpulkan Pengendalian Internal secara individual berpengaruh secara positif dan signifikan terhadap Kualitas Sistem Informasi Akuntansi Manajemen.

Hal ini sesuai dengan hasil penelitian yang dilakukan oleh Fadila Ariesta (2013) menyebutkan bahwa terdapat pengaruh secara signifikan dan positif Pengendalian Internal terhadap Kualitas Sistem Informasi Akuntansi Manajemen.

\section{Hipotesis 3 Teknologi Informasi dan Pengendalian Internal secara bersama-sama} berpengaruh terhadap Kualitas Sistem Informasi Akuntansi Manajemen.

Hasil pengujian uji $\mathrm{F}$ menunjukan bahwa nilai signifikan sebesar 0,002 lebih kecil dari a, sehingga dapat disimpulkan bahwa variabel independen secara bersama-sama berpengaruh secara signifikan terhadap Kualitas Sistem Informasi Akuntansi Manajemen.

Tabel 4. Ringkasan Pengaruh Variabel Independen terhadap Variabel Dependen

\begin{tabular}{|c|c|c|}
\hline Variabel & $\begin{array}{c}\text { Arah } \\
\text { Pengaruh }\end{array}$ & Signifikan \\
\hline Teknologi Informasi & Positif & Signifikan \\
\hline Pengendalian Internal & Positif & Signifikan \\
\hline $\begin{array}{c}\text { Teknologi Informasi dan } \\
\text { Pengendalian Informasi }\end{array}$ & Positif & Signifikan \\
\hline
\end{tabular}

Sumber: Hasil Uji Signifikan t SPSS 2020

\section{PEMBAHASAN}

Pada bagian ini akan dilakukan pembahasan uji atas hasil penelitian tentang pengaruh Teknologi Informasi dan Pengendalian Internal terhadap Kualitas Sistem Informasi Akuntansi Manajemen pada perushaan AUTO2000 Kenjeran yang ada di Kecamatan Mulyorejo Surabaya tahun 2020. Pembahasan masing-masing variable disajikan sebagai berikut:

\section{Pengaruh Teknologi Informasi Berpengaruh Signifikan Terhadap Kualitas Sistem Informasi Akuntansi Manajemen}

Hasil penelitian menunjukkan bahwa variable Teknologi Informasiberpengaruh positif dan signifikan terhadap Kualitas Sistem Informasi Akuntansi Manajemen di AUTO2000 Kenjeran Kecamatan Mulyorejo Surabaya. Hal ini dibuktikan dengan nilai $t_{\text {hitung }}$ lebih besar dari pada $t_{\text {tabal }}(2,771>2,46714)$, signifikansi sebesar $0,010<0,05$. Maka penelitian ini berhasil membuktikan hipotesis pertama yang menyatakan Teknologi Informasi berpengaruh positif dan signifikan terhadap Kualitas Sistem Informasi Akuntansi Manajemen di AUTO2000 Kenjeran Kecamatan Mulyorejo Surabaya. Hal ini menunjukkan bahwa Teknologi Informasi mempunyai 
pengaruh yang signifikan terhadap Kualitas Sistem Informasi Akuntansi Manajemen maka model regresi dapat di gunakan untuk memprediksi Kualitas Sistem Informasi Akuntansi Manajemen. sehingga dapat di simpulkan bahwa Teknologi Informasi (X1) berpengaruh secara persial terhadap Kualitas Sistem Informasi Akuntansi Manajemen (Y) . Hal ini berarti H1 di terima, artinya ada pengaruh Teknologi Informasi terhadap kinerja.

Dapat di artikan juga bahwa semakin baik Teknologi Informasi akan berpengaruh terhadap optimalnya Kualitas Sistem Informasi Akuntansi Manajemen yang di capai begitu sebalikanya semakin tidak baik Teknologi Informasi akan berpengaruh semakin rendahnya kinerja yang di capai.

\section{Pengaruh Pengendalian Internal Terhadap Kualitas Sistem Informasi Akuntansi Manajemen}

Berdasarkan pada analisis deskriptif presesntase maka variabel Pengendalian Internal menunjukan bahwa 30 responden yang di teliti, sebanyak $11(36,67 \%)$ jawaban responden menunjukan Pengendalian Internal sangat baik, 19 (63,33\%) jawaban responden menunjukan bahwa Pengendalian Internal baik.

Hasil penelitian menunjukkan bahwa variable Pengendalian Internal berpengaruh positif dan signifikan terhadap Kualitas Sistem Informasi Akuntansi Manajemen di AUTO2000 Kenjeran Kecamatan Mulyorejo Surabaya . Hal ini dibuktikan dengan nilai $t_{\text {hitung }}$ lebih besar dari pada $t_{\text {tabel }}(2500>2,4617)$, signifikansi sebesar $0,0010<0,05$. Maka (H2) di terima penelitian ini berhasil membuktikan hipotesis kedua yang menyatakan Pengendalian Internal (X2) berpengaruh terhadap Kualitas Sistem Informasi Akuntansi Manajemen (Y).

Dapat di artikan juga bahwa semakin tinggi Pengendalian Internal akan berpengaruh terhadap kenaikan Kualitas Sistem Informasi Akuntansi Manajemen yang di capai begitupun sebaliknya semakin rendah kegiatan Pengendalian Internal akan berpengaruh semakin rendahnya Kualitas Sistem Informasi Akuntansi Manajemen yang di capai.

\section{Pengaruh Teknologi Informias Dan Pengendalian Internal Terhadap Kualitas Sistem Informasi Akuntansi Manajemen}

Berdasarkan pada hasil analisis berganda dengan bantuan SPSS menunjukan bahwa secara simultan, Teknologi Informasi dan Pengendalian Internal berpengaruh terhadap Kualitas Sistem Informasi Akuntansi Manajemen yang di tunjukan dengan nilai F hitung sebesar 7,693 dengan signifikan sebesar 0,002 , hal ini menunjukan bahwa nilai $F$ yang di peroleh signifikan karena harga signifikasi kurang dari 0,05 , hal ini berarti (H3) di terima artinya ada pengaruh secara bersama sama antara Teknologi Informasi dan Pengendalian Internal terhadap Kualitas Sistem Informasi Akuntansi Manajemen.

Besarnya antara pengaruh Teknologi Informasi dan Pengendalian Internal terhadap Kualitas Sistem Informasi Akuntansi Manajemen secara simultan dapat di ketahui dari nilai $\left(\boldsymbol{R}^{2}\right)$ 0,587 atau 58,7 \% jadi Teknologi Informasi dan Pengendalian Internal terhadap Kualitas Sistem Informasi Akuntansi Manajemen secara bersama-sama berpengaruh terhadap Kualitas Sistem Informasi Akuntansi Manajemen sebesar 58,7\% dan sisanya 41,3\% di pengaruhi oleh fator lain yang tidak di kaji dalam penelitian ini.

Berdasarkan uraian di atas dapat di simpulkan bahwa Teknologi Informasi dan Pengendalian Internal berpengaruh terhadap Kualitas Sistem Informasi Akuntansi Manajemen. Oleh karena itu perusahaan ini harus meningkatkan sistem Teknologi Informasi dan Pengendalian Internal agar Kualitas Sistem Informasi Akuntansi Manajemen mereka maksimal. 


\section{KESIMPULAN DAN SARAN}

Berdasarkan hasil kesimpulan dan analisis pada bab sebelumnya maka dapat di simpulkan bahwa:

1. Bahwa analisis deskriptif menunjukan bahwa dari 30 yang di teliti Kualitas Sistem Informasi Akuntansi Manajemen jawaban 15 responden (50\%) menunjukan Kualitas Sistem Informasi Akuntansi Manajemen baik, jawaban 1 responden ( 3,33\%) menunjunjukan Kualitas Sistem Informasi Akuntansi Manajemen yang kurang baik, 14 responden $(46,67)$ menunjukan Kualitas Sistem Informasi Akuntansi Manajemen yang sangat baik. Pada Teknologi Informasi 8 terdapat 1 responden $(3,33 \%)$ menunjukan jawaban bahwa tingkat Teknologi Informasi sangat tinggi, $11(36,66 \%)$ jawaban responden menunjukan tingkat Teknologi Informasi tinggi, 18 (60\%) jawaban responden menunjukan tingkat Teknologi Informasi sedang. Pada Pengendalian Internal menunjukan bahwa 30 responden yang diteliti sebayak $11(36,67 \%)$ jawaban responden menunjukan Pengendalian Internal sangat baik , $19(63,33 \%)$ jawaban responden menunjukan bahwa sistem Pengendalian Internal baik.

2. Ada pengaruh yang signifikan antara Teknologi Informasi terhadap Kualitas Sistem Informasi Akuntansi Manajemen, yang berarti semakin meningkat Teknologi Informasi akan diikuti dengan kenaikan Kualitas Sistem Informasi Akuntansi Manajemen. Hal ini ditunjukan dari hasil t yang di peroleh dari t hitung 2,771 dengan signifikan $0.010<0,05$.

3. Ada pengaruh signifikan antara sistem Pengendalian Internal terhadap Kualitas Sistem Informasi Akuntansi Manajemen yang berarti semakin meningkatnya sistem Pengendalian Internal akan diikuti dengan Kualitas Sistem Informasi Akuntansi Manajemen. Hal ini ditunjukan dari hasil uji t diperoleh t hitung 2,500 dengan signifikan 0,019<0,05.

4. Ada pengaruh signifikan antara Teknologi Informasi dan Pengendalian Internal terhadap Kualitas Sistem Informasi Akuntansi Manajemen. Hal ini ditunjukan dari uji f di peroleh hasil 7,639 dengan signifikan $0.002<0,05$.

5. Penerapan Teknologi Informasi pada AUTO2000 Kenjeran akan menjadikan perusahaan lebih fleksisbel dan lebih bervariatif dan mendukung jaringan cabang / operasional yang lebih luas, perusahaan ini juga dapat tumbuh lebih cepat dan mengambil peran lebih besar dalam perekonomian. Penerepan Teknologi Informasi dari pusat ke cabang -cabang harus diikuti dengan sistem Pengendalian Internal yang baik karena kemampuan Kualitas Sistem Informasi Akuntansi Manajemen harus di dukung dengan informasi secara tepat dan akurat sehingga dapat miningkatkan Kualitas Sistem Informasi Akuntansi Manajemen.

Dari hasil penelitian ini, maka peneliti menyarankan:

1. Disarankan kepada perusahaan untuk benar-benar melaksanakan teknologi informasi khusunya dalam hal pengambilan kebijakan oprasional, hal ini akan semakin mendorong manajer dan teamnya untuk lebih kreatif menentukan gagasan-gagasan baru untuk mendukung tercapainya tujuan organisasi dan terciptanya kualitas sistem informasi akuntansi manajemen yang lebih tinggi, kepercayaan yang di berikan kepada manajer divisi justru sangat memungkinkan untuk memperoleh informasi akuntansi manajemen lebih akurat, broad scope, timelines agregatiom, integration karena mereka saling mengerti solusi atas persoalan persoalan yang harus dipecahkan dalam bidangnya masing-masing.

2. Adanya hubungan interaksi antar variabel akan membantu para manajer untuk mengidentifikasi interaksi yang mungkin dapat menjadi suatu sinergi terhadap keberhasilan tercapainya tujuan orgaisasi.

3. Teknologi informasi dari pusat ke cabang-cabang harus diikuti kemampuan sistem informasi akuntansi manajemen, peningkatan kualitas sistem informasi akuntansi 
manajemen harus didukung juga dengan pengendalian internal dalam memberikan informasi sehingga penerapan teknologi informasi bisa berjalan dengan baik.

\section{DAFTAR PUSTAKA}

Abdul Kadir, 2005, Pengenalan Sistem Informasi, Andi, Yogyakarta

Arikunto, S. (2013). Prosedur Penelitian: Suatu Pendekatan Praktik. Jakarta: Rineka Cipta.

Garrison, R,H. Noreen, E, W. Brewer. (2010). Managerial Accounting. 13thed.Mc. Graw-Hill. New York.

Hansen \& Mowen. 2004. Manajemen Biaya, Edisi Bahasa Indonesia. BukuKedua. Jakarta: Salemba Empat

Jogiyanto, H.M. 2005, Analisa dan Desain Sistem Informasi: PendekatanTerstruktur Teori dan Praktik Aplikasi Bisnis, ANDI, Yogyakarta

Putu Mega. 2012. Penerapan Pengendalian Internal Dalam Sistem InformasiAkuntansi Berbasis Komputer. Jurnal Ilmiah Mahasiswa Akuntansi - Vol. 1, No. 4, Juli 2012.

Siti Kurnia Rahayu, 2010. PERPAJAKAN INDONESIA : Konsep dan AspekFormal, Yogyakarta : Graha Ilmu

Sri Maharsi. 2000. Pengaruh Perkembangan Teknologi Informasi TerhadapBidang Akuntansi Manajemen. Jurnal Akuntansi \&Keuangan Vo.2, No. 2, Nopember 2000:127-137.

Sugiyono. 2012. Metode Penelitian Kombinasi. Bandung: Alfab

Sunarto. 2003. Manajemen Pemasaran. Yogyakarta: BPFE-UST.

Sutabri Tata, 2016, Sistem Informasi Manajemen, Andi Offset, Yogyakarta.

Sutarman. 2009. Pengantar teknologi Informasi. Jakarta : Bumi Aksara

Syairozi, M. I. (2021). Analisis Kemiskinan di Sektor Pertanian (Studi Kasus Komoditas Padi di Kabupaten Malang). Media Ekonomi, 28(2), 113-128.

Yasin, Muhammad. "The Influence Of Profitability And Capital Structure On Company Value In Coal Sub-Sector Mining Companies Registered In Idx For The 2014-2017." Enrichment: Journal of Management 11, no. 2 (2021): 516-520.

Zulganef, 2008. Metode Penelitian Sosial dan Bisnis, Cetakan Pertama, Grahallmu, Yogyakarta. 